\title{
The protection of cultural heritage: common heritage of humankind, national cultural 'patrimony' or private property?
}

\author{
FIONA MACMILLAN
}

Professor of Law, Birkbeck, University of London

\begin{abstract}
$\underline{\text { Abstract }}$
Starting from an argument about the relationship between cultural heritage and national and/or community identity, this article considers the different ways in which both the international law regime for the protection of cultural heritage and the international intellectual property regime tend to appropriate cultural heritage. The article argues that, in the postcolonial context, both these forms of appropriation continue to interfere with the demands for justice and for the recognition of historical wrongs made both by indigenous peoples and by many developing countries. At the same time, the article suggests that these claims are undermined by the misappropriation of the postcolonial discourse with respect to restitution of cultural heritage, particularly in the intra-European context. The article advocates the need for a regime for the protection of cultural heritage that is strong enough to resist its private appropriation through the use of intellectual property rights and nuanced enough to recognise significant differences in the political context of local and national claims to cultural heritage.
\end{abstract}

\section{Introduction}

This article is located in the context of persistent assertions in international legal 1 instruments characterising cultural patrimony as being the heritage of humankind. The significance of this assertion is contested: it is unclear whether it amounts to a claim of 'ownership', a justification for legal protection, or a(nother) piece of convenient legal verbiage lacking precise significance or meaning. Taking account of these mutations in meaning, the article traces the emergence of the legal concept of cultural heritage with a view to demonstrating that it has always been a critical factor in the development of national identity and the securing of national sovereignty. It argues that, in substance, international law has failed to address the significance of national cultural patrimony in the development process. This failure is not only manifested by the vague language of international instruments, which do not adequately address the connection between concepts of community, nation, state and that of cultural heritage. It is also a consequence of the promotion of an aggressive system of intellectual property protection that frequently has the effect of privatising cultural property ${ }^{1}$ in the hands of individuals,

1 In general this article uses the expression 'cultural property' interchangeably with that of 'cultural heritage'. For an account of the movement in international law from the use of the former expression to the use of the latter, see J Blake, 'On Defining the Cultural Heritage' (2000) 49 International and Comparative Law Quarterly 61-85, 65-67. While Blake's account explains the advantages of the use of 'heritage' rather than 'property' 
corporate or human, when it might be more properly managed as a community resource or right. In the end, one way or another, law (mis)appropriates the cultural heritage of communities, nations or states. This (mis)appropriation arguably amounts to yet another instance of the denial of any meaningful concept of development in international law.

\section{Heritage, identity, sovereignty}

The connection between heritage, identity and sovereignty is well known to those who have followed the debate in relation to the rights of indigenous people over their cultural heritage. The United Nations Declaration on the Rights of Indigenous People ${ }^{2}$ contains numerous manifestations of the importance attached to this concept, ${ }^{3}$ which traverse rights in both tangible and intangible heritage. These concepts are found in Articles 11.1, 12.1 and 13.1, which provide respectively:

[Article 11.1:] Indigenous peoples have the right to practise and revitalize their cultural traditions and customs. This includes the right to maintain, protect and develop the past, present and future manifestations of their cultures, such as archaeological and historical sites, artefacts, designs, ceremonies, technologies and visual and performing arts and literature.

[Article 12.1:] Indigenous peoples have the right to manifest, practise, develop and teach their spiritual and religious traditions, customs and ceremonies; the right to maintain, protect, and have access in privacy to their religious and cultural sites; the right to the use and control of their ceremonial objects; and the right to the repatriation of their human remains.

[Article 13.1:] Indigenous peoples have the right to revitalize, use, develop and transmit to future generations their histories, languages, oral traditions, philosophies, writing systems and literatures, and to designate and retain their own names for communities, places and persons.

Articles 11.2, 12.2 and 13.2, meanwhile, impose obligations on states with respect to the protection of these rights, as well as redress and restitution in cases where the rights have been infringed. The Declaration's main assertion with respect to cultural heritage, however, is in Article 31.1, which also has the effect of linking cultural heritage and intellectual property rights:

Indigenous peoples have the right to maintain, control, protect and develop their cultural heritage, traditional knowledge and traditional cultural expressions, as well as the manifestations of their sciences, technologies and cultures, including human and genetic resources, seeds, medicines, knowledge of the properties of fauna and flora, oral traditions, literatures, designs, sports and traditional games and visual and performing arts. They also have the right to maintain, control, protect and develop their intellectual property over such cultural heritage, traditional knowledge, and traditional cultural expressions.

[note 1 continued] in terms of the width of its application, I suspect that this change in language also obscures the dimensions of the systemic conflict between cultural property/heritage and intellectual property, which is one of the themes of this article. It is notable that other writers who are concerned with this conflict, tend to use the expression cultural property, rather than cultural heritage: see, e.g., J R Slaughter, 'Form and Informality: An Unliterary Look at World Literature' in R Warhol, The Work of Genre: Selected Essays from the English Institute (English Institute in Collaboration with the American Council of Learned Societies 2011) <http://quod.lib.umich.edu/cgi/t/text/text-idx?c=acls;idno=heb90055> 177-240.

2 GA Res 61/295 (UN Doc A/61/L67 and Add 1), adopted on 13 September 2007.

3 While at the same time making reference to the ubiquitous concept of the common heritage of humankind in a preambular statement that affirms that 'all peoples contribute to the diversity and richness of civilizations and cultures, which constitute the common heritage of humankind'. 
The long campaign of indigenous peoples which resulted in this Declaration is linked to a wider agenda of self-determination, ${ }^{4}$ which is ethically and politically connected to the treatment of indigenous peoples during the colonial and postcolonial periods. This historical context provides a clear basis for distinguishing the claims of indigenous peoples from some other examples where the assertion of rights over cultural heritage has become the centrepiece of national identity and/or claims to sovereignty.

In the European context, the assertion of national rights over cultural heritage has become part of the policy platform of right-wing and, in some cases, extreme right-wing parties, the effective claim of which is that national identity is so closely tied up with this 'heritage' that its relocation is a matter of cultural 'right'. This, for example, is part of the platform of the Danish People's Party. The Program of which contains numerous references to the importance of Danish national cultural heritage. ${ }^{5}$ The third of four paragraphs that serve to introduce the Program states: 'In the Danish People's Party we are proud of Denmark; we love our country and we feel a historic obligation to protect our country, its people and the Danish cultural heritage.' And there is further section concerned specifically with the importance of cultural heritage:

\section{The country is founded on the Danish cultural heritage and therefore, Danish culture must be preserved and strengthened.}

This culture consists of the sum of the Danish people's history, experience, beliefs, language and customs. Preservation and further development of this culture is crucial to the country's survival as a free and enlightened society.

Therefore we wish to see action on a broad front to strengthen the Danish national heritage everywhere. Outside Denmark's borders we would like to give financial, political and moral support to Danish minorities. ${ }^{6}$

In furthering claims based on this platform, this political party has not hesitated to misappropriate the discourse on postcolonialism that has sustained the claims of indigenous peoples. ${ }^{7}$ As Porsdam has shown, this misappropriation is well illustrated in relation to the controversy over the return to Denmark of the surviving versions of the Jyske Lov (Jutlandic Law) of 1241, which was in the possession of the Swedish Royal Library, having either been purchased by it or bequeathed to it in the early eighteenth century. ${ }^{8}$ Despite the claims of the Danish People's Party that the case was comparable to the dispute in the 1970 s over the return to Iceland by Denmark of the Icelandic Sagas, ${ }^{9}$ the two can probably be distinguished, politically at least, on the basis of the former imperial relationship between Denmark and Iceland. During the nineteenth and twentieth centuries,

4 Despite Art 46.1 of the Declaration, which apparently represents the type of political and diplomatic compromise common in international legal instruments. It provides: 'Nothing in this Declaration may be interpreted as implying for any State, people, group or person any right to engage in any activity or to perform any act contrary to the Charter of the United Nations or construed as authorizing or encouraging any action which would dismember or impair, totally or in part, the territorial integrity or political unity of sovereign and independent States.'

5 <www.danskfolkeparti.dk/The_Party_Program_of_the_Danish_Peoples_Party.asp> accessed 29 January 2013. My thanks to Professor Helle Porsdam of the University of Copenhagen for drawing my attention to this material.

6 Ibid (bold as in the original).

7 H Porsdam, 'Cultural Heritage and Law: The Case of Cultural Looting' in H Porsdam and T Elholm (eds), Dialogues on Justice: European Perspectives on Law and Humanities (De Gruyter 2012) 219-34, 221 and 228-32.

8 Ibid 228-32.

9 As to which, see M Rendix, 'Copyright as Moral Strategy of Reclaiming the Past: The Return of the Icelandic Sagas' in Porsdam and Elholm ( n 7) 177-92. 
the Icelandic Sagas had been at the centre of a long campaign by Iceland based on the assertion that these manuscripts were central to their national identity. Greenfield observes:

The significance of these saga manuscripts to the people of Iceland would be impossible to exaggerate. They have been the root and stock of Icelandic culture, the lifeblood of the nation, the oldest living literature in Europe, enshrining the origins of Icelandic society ... Indeed, when the Icelanders took up the struggle for freedom and independence from Denmark in the nineteenth century, the saga literature was both their inspiration and their justification. ${ }^{10}$

With respect to questions about the relationship between ownership as a legal matter and claims for the return of cultural heritage on the basis of some form of national right, there is less to distinguish the cases. Allowing for the fact that the passage of time tends to obscure some relevant details, it is arguably the case that both the Icelandic Sagas and the Jutlandic Law were legitimately acquired by Denmark ${ }^{11}$ and Sweden, ${ }^{12}$ respectively. This same tension between the question of whether the item of cultural heritage was legitimately acquired by the holder and the right (in any case) to claim return of such items is a feature of many current controversies. Other salient examples of this are, of course the longrunning dispute over the Elgin Marbles ${ }^{13}$ and the current claim by Turkey for the return of sculptures from the Mausoleum of Halicarnassus, which are currently part of the British Museum collection. ${ }^{14}$

Given the alleged relationship between national cultural heritage and identity, it is not surprising that 'ownership' of cultural heritage is also a part of the contested territory of sovereignty and challenges to sovereignty, in a world that is not perhaps quite as globalised (for better or worse) as one might sometimes be tempted to think. Arguably, the current campaign by Turkey for the return of artefacts that it considers its national property, ${ }^{15}$ of which the claim for the return of the sculptures from the Mausoleum of Halicarnassus is one, represents an assertion of sovereignty in the face of Western hostility. ${ }^{16}$ This campaign, however, is one that should be easily recognisable to former imperial states, since it appears to have been mounted with the intention of stocking an 'encyclopaedic museum like the Metropolitan or British Museum'. ${ }^{17}$ As this comment makes clear, the concept of preserving and exhibiting cultural heritage in this way is a familiar and comfortable way of expressing a claim to identity and sovereignty. Preservation and conservation of cultural heritage, in particular, is a value to which Western society tends to subscribe. ${ }^{18}$ One consequence of this is that claims to proprietary rights over cultural heritage as assertions

10 J Greenfield, The Return of Cultural Treasures (CUP 1996) 4, quoted in Rendix (n 9) 180.

11 Rendix (n 9) 181.

12 Porsdam (n 7) 229.

13 See e.g. <www.elginism.com> accessed 29 January 2013.

14 See e.g. 'Turkish Campaigners May Go to European Court of Human Rights over Mausoleum of Halicarnassus in British Museum' <www.elginism.com/similar-cases/turkish-compaigners-may-go-toeuropean-court-of-human-rights-over-mausoleum-of-halicarnassus-in-british-museum/20121217/6770/> accessed 29 January 2013.

15 See e.g. 'Of Marbles and Men: Turkey Gets Tough with Foreign Museums and Launches a New Culture War' The Economist (19 May 2012) <www.economist.com/node/21555531> accessed 3 February 2013.

16 An example of which is the negative reaction on the part of some states in the European Union to the idea of admitting Turkey to the Union. See also ibid, in which it is observed that ' $\mathrm{g}]$ rowing economic power and stalled talks over EU membership make many Turks feel that it is time to turn their backs on the West. Amid the turmoil of the Arab spring Turkey believes it can become the leader of the region.'

17 A quote attributed to an aide to Turkey's Minister for Culture and Tourism, Ertugrul Gunay: ibid.

18 See P Yu, 'Cultural Relics, Intellectual Property and Intangible Heritage' (2008) 81 Temple Law Review 433, $471-73$. 
of sovereignty that involve practices that do not amount to conservation of that cultural heritage can be regarded as extremely problematic.

We can all sit around and nod our heads sagely when we are told that the destruction by the Zuni of their war gods forms part of a cultural practice that should be respected and that the attempt to preserve these gods would be culturally disrespectful; ${ }^{19}$ or likewise, when the Igbo people destroy their mbaris as part of a cultural practice, after having painstakingly erected them. ${ }^{20}$ Yet no such indulgence was evident when the Taliban regime in Afghanistan dynamited the World Heritage-listed, sixth-century Buddhas of Bamiyan, having described them as being 'idols' and thus religiously offensive. The cases clearly have significant differences, one of the more important in cultural terms being that the Taliban were destroying something that belonged not to their own culture, but arguably to someone else's, although they claimed a cultural imperative for the act of destruction. However, the Bamiyan Buddhas case is probably most interesting because of its significance in geopolitical terms. A reasonable argument might be made that this was much more than a mere act of cultural destruction. It was, rather, an aggressive assertion of sovereignty, not to mention a clear rejection of any meaningful concept of the common heritage of humanity, in favour of a claim that the Buddhas were part of their national cultural patrimony to do with as they wished.

\section{The common heritage of humanity?}

Of course, most controversies involving some sort of national, local or community assertion of rights over cultural heritage do not, as a matter of logical necessity, involve the rejection of the concept of the common heritage of humankind. Instead, they tend to involve some contingent claim that, for one reason or another, is said to trump or displace other claims. For example, it is not necessarily clear that claims made by the British Museum to retain their extensive collection of heritage objects from all around the world involve a rejection of the concept of the common heritage of humanity in favour of some claim to national rights over the contents of the museum. Rather the Director of the Museum, Ewan McGregor, claims that they are in the best position to conserve the artefacts and to present this 'encyclopaedic collection'21 - a position that Sharon Waxman scathingly describes as 'this new philosophy for a multicultural age'. 22 There is also a faux naivety in this idea of the 'encyclopaedic collection' as though it was somehow free of the circumstances in which it was formed, and as though all the components of the collection will look exactly the same from wherever they are viewed. ${ }^{23}$ Observations made by Slaughter when addressing the concept of 'the centre' in the intangible cultural heritage of world literature seem apposite here:

19 S Harding, 'Value, Obligation and Cultural Heritage' (1999) 31 Arizona State Law Journal 291, 312; R W Mastalir, 'A Proposal for Protecting the "Cultural" and "Property" Aspects of Cultural Property under International Law' (1993) 16 Fordham International Law Journal 1033, 1038; Yu (n 18) 476-78.

20 See Harding (n 19) 309-12; Yu (n 18) 476-78.

21 N MacGregor, 'Preface' in K Sloan (ed), Enlightenment: Discovering the World in the Eighteenth Century (British Museum Press 2004) 6. See also, N MacGregor, "To Shape the Citizens of "That Great City, the World" in J Cuno (ed), Whose Culture? The Promise of Museums and the Debate over Antiquities (Princeton University Press 2009) 39-54.

22 S Waxman, Loot: The Battle over the Stolen Treasures of the Ancient World (Times Books, Henry Holt \& Co 2008) 212.

23 See further G Rose, Visual Methodologies: An Introduction to Researching with Visual Materials (3rd edn, Sage 2012). My thanks to Professor Amanda Perry-Kessaris for this reference. 
$[T]$ he core defines the norms and forms that make it the core; it defines itself as center ... We should remember, here at the center, that the core is the core not because it is the source of things, but because it is a collection of things ... [T] he center absorbs everything; it ... treats everywhere else and everything else as raw materials to be extracted, exploited, accumulated, and privatized ... [T] he center is never simply a given or merely an object; it is the effect of a certain way of seeing and speaking, of gathering and analyzing data. ${ }^{24}$

What McGregor does not say, because he is obviously alive to the dangers of it, is that the great metropolitan museums, like the British Museum, are, of course, a sort of physical embodiment of the history of imperialism. This is a description that the British Museum may not be willing to embrace, but in some senses it could be taken as the basis for an argument that the British Museum has some particular interest, beyond the presentation of an encyclopaedic collection, in keeping all this looted stuff because it is part of British history and, thus, perhaps of British cultural heritage - although maybe this confuses history with heritage. However, if the British Museum could make such a claim then how would it relate to claims for return of artefacts to former colonies, and to communities within former colonies, on the basis of their significance to history and identity? Whose claim trumps whose?

All these types of controversies, and their intensely political nature, clearly have the capacity to complicate how we talk about ownership of, or rights over, cultural heritage at any level more specific than common heritage of humanity. However, the concept of the common heritage of humanity does not necessarily preclude us from talking at the same time about national, local or community rights or responsibilities in relation to heritage. This is to say that the battle over the ownership of cultural heritage has always been an ongoing battle over history and how it relates to or is translated into present-day identity.

\section{Cultural heritage in international law}

The trajectory of international law in this area is clearly marked by precisely this battle. And like the controversies over the collections in the great metropolitan museums, it also tends to reveal the rather contingent historical and political nature of at least some 'national' and local claims to cultural heritage.

Although disputes about ownership of cultural artefacts go back to antiquity, ${ }^{25}$ cultural heritage first became a recognised concept in international law at the time of the Vienna Treaty of $1815,{ }^{26}$ which was imposed by the British victors after the conclusion of the Napoleonic Wars. One of the things that the British insisted upon was the return of moveable artefacts of 'cultural heritage' looted by Napoleon during his campaigns. This was very much a punitive clause, but it carried with it the rise of a discourse that linked people, territory and cultural objects. ${ }^{27}$ Naturally, the discourse was essentially European in perspective, but even more it was guided by British imperial claims. A stroll through the Italian galleries in the Louvre makes it clear that a substantial collection of Venetian artworks, looted by Napoleon, remain in French possession. The British, it seems, may have been less than diligent in enforcing the terms of the Vienna Treaty when they did not relate directly to British interests. The Venetians, however, did get back the famous horses of San Marco, one of the symbols of their city. The extent to which this might be considered a victory of cultural heritage rights perhaps needs to be considered in light of the fact that

24 Slaughter (n 1) 196.

25 See M M Miles, Art as Plunder: The Ancient Origins of Debate about Cultural Property (CUP 2010).

26 A F Vrdoljak, International Law, Museums and the Return of Cultural Objects (CUP 2008) 23-29.

27 Ibid 13, citing W G Grewe, The Epochs of International Law, M Byers (trans and rev) (De Gruyter 2000) xviii. 
the Venetians had looted the horses from Corinth several centuries earlier. In fact, this example is illustrative of a perennial issue with respect to national or local rights in cultural heritage, which is that the passage of time, along with the mutations of nationality and national borders, tends to introduce a certain fragility into some current assertions of national ownership. For example, the fact that the sculptures from the Mausoleum of Halicarnassus, the subject of Turkey's claim against the British Museum, were made by Greek sculptors 28 is not without some resonance in this context.29

The period prior to the conclusive end of British dominance, which was definitely dead by the end of the Second World War, ${ }^{30}$ was, amongst other significant events in the present context, ${ }^{31}$ characterised by the systematic removal of cultural objects, without any sense of moral culpability, from the 'outposts' of the Empire. ${ }^{32}$ The subsequent treatment of this process of removal, under both international law and under the administrative practice of former metropolitan states, in the period of decolonisation after the end of the Second World War has laid the groundwork for the issues with which this article is most closely concerned. There are three inter-related aspects of the terrain of international law that need to be taken into account in order to reflect on the trajectory of international law and its impact on the relationship between development and cultural heritage rights.

First of all, there is the very process of decolonisation itself and the political aspirations that accompanied it. At the international law level, this process was managed in a rather $e x$ post facto fashion by something that eventually became yet another in the extensive collection of 'Vienna' treaties and conventions. This was the Vienna Convention on the Succession of States in Respect of State Property, Archives and Debts of 1983. In the current context there are two key (low) points of this treaty. The first of these is its failure to recognise the distinctive position of indigenous peoples within former colonial subject states. This, of course, is a serious problem with which the international law system continues to struggle. In part, it was a consequence of the strongly state-based thinking that characterised the development of international law in the post-war period. This explanation (the inadequacy and injustice of which needs no elaboration), however, cannot serve to explain the second important aspect of the Vienna Convention, which is the absence of any rules on restitution of works of art or artefacts to the former colonial states. Instead, the question of the return of works of art and artefacts was to be governed by bilateral negotiations under the auspices of a UNESCO Committee, the operation of which has continued up until the present period. ${ }^{33}$ What makes this particularly pernicious is the stark contrast between the arrangements that the colonial powers, comprising a number of European states, made with respect to the return of artefacts to their former colonies and the

28 'Of Marbles and Men' (n 15).

29 Another example of this type of problem relates to the murals of Bruno Schulz: see M Bruncevic, 'The Lost Mural of Bruno Schulz: A Critical Legal Perspective on Control, Access to and Ownership of Art' (2011) 22 Law and Critique 79-96.

30 G Arrighi, The Long Twentieth Century: Money, Power and the Origins of Our Times (Verso 1994) 47-74 and ch 3.

31 Including: the conclusion of the first specific international law instrument designed to protect cultural heritage (1907 Hague Regulations on Law and Customs of War: Protection of Historic Buildings); and the rise of ideology in European fascist states that postulated the destruction or removal of cultural objects as essential to eradicating the identity and existence of certain groups.

32 Special Rapporteur, Mohammed Bedjaoui, who was responsible for the preparation of the work that eventually led to the conclusion of the Vienna Convention on Succession of States in respect of State Property, Archives and Debts (1983) found that the removal of cultural objects during the colonial period was generally not 'in accordance with the canons of justice, morality and law': UN Doc A/CN4/292, quoted in Vrdoljak (n 26) 202.

33 For a critical assessment of the work of this committee, see Vrdoljak (n 26) 211-17. 
arrangements that they made for the return of what they considered to be their own artefacts under the Allied Restitution programmes that followed the conclusion of the Second World War. ${ }^{34}$

The second of the three important developments in international law in the postcolonial period was the re-institutionalisation of the concept of free trade. This occurred as a result of the Bretton Woods negotiations at the conclusion of the Second World War, and specifically the conclusion of the General Agreement on Tariffs and Trade, which constituted part of Roosevelt's envisaged remaking of the world systems. The concept of international free trade had been floating around since the Treaty of Westphalia of 1649, which had abolished trade barriers and sought to protect the rights of private enterprise to trade across state borders, even during times of war or other political turmoil. ${ }^{35}$ While the economic freedoms of Westphalia were not observed during the Napoleonic Wars, they were restored in the Settlement of Vienna of 1815 and the Congress of Aix-la-Chapelle of 1818. ${ }^{36}$ And then these freedoms were restored again, after the cataclysms of the First and Second World Wars, at Bretton Woods, starting the international legal system(s) on a process that has lead eventually to the World Trade Organization (W'TO).

Thirdly, the postcolonial period has also witnessed the development of the UNESCO regime for the protection of 'culture', within the international law context of the Dumbarton Oaks system. The Dumbarton Oaks system, arising from the Dumbarton Oaks negotiations also at the end of the Second World War, set up the UN system and set the scene for much of what we now call public international law. The UNESCO Conventions started off with a concern for the protection of cultural property during armed conflict (UNESCO Convention on the Protection of Cultural Property in the Event of Armed Conflict (Hague Convention, 1954)), moved on a concern for restitution to states of moveable cultural property (UNESCO Convention on the Means of Prohibiting and Preventing the Illicit, Import, Export and Transfer of Ownership of Cultural Property 1970), and then the preservation of immoveable cultural property (UNESCO Convention Concerning the Protection of the World Cultural and Natural Heritage 1972). In this century, while the rate of international law-making with respect to the protection of culture and cultural heritage has increased, the focus of protection has moved to a concern for underwater cultural heritage (UNESCO Convention on the Protection of the Underwater Cultural Heritage 2001), intangible cultural heritage (UNESCO Convention for the Safeguarding of Intangible Cultural Heritage 2003) and the concept of 'cultural diversity' (UNESCO Convention for the Protection and Promotion of the Diversity of Cultural Expressions 2005).

What is particularly important and interesting about this UNESCO regime is that it marked by its reactions to both the process of decolonisation and the growth and development of free-trade theory. Despite using the language of the cultural heritage of mankind/humanity, the regime is intensely statist, which is also (obviously) a consequence of its location in the system of international law. This, of course, reflects the strongly statist ideology that characterised the period of decolonisation. There are now some small breaches in this discourse as witnessed at the general level on public international law, for example, in the UN Declaration on the Rights of Indigenous Peoples of 2007 and reflected in the

34 Vrdoljak (n 26) 202. And for an account of the Allied Restitution programmes in this context, see ibid 140-48.

35 Arrighi (n 30) 43-44.

36 Ibid 52. 
UNESCO Convention for the Safeguarding of Intangible Cultural Heritage ${ }^{37}$ and the Convention for the Protection and Promotion of the Diversity of Cultural Expressions..$^{38}$ At the same time, and arguably running counter to this strongly statist approach, the ambit of the UNESCO regime is circumscribed by the dominance of free trade ideology and the associated importance of private ownership rights. One classic example of this is the UNESCO Convention on the Means of Prohibiting and Preventing the Illicit, Import, Export and Transfer of Ownership of Cultural Property of 1970, which makes its provisions on the return of moveable cultural property subject to ensuring compensation for 'innocent' purchasers and persons 'who have valid titles' to the relevant artefacts. ${ }^{39}$ The Convention for the Protection and Promotion of the Diversity of Cultural Expressions is also marked by the dominance of free-trade ideology. In one way, its very existence can be considered a reaction to the international legal implementation of that ideology in the WTO agreements. This is because one of primary motivations of the Convention's promoters was to compensate for the absence of a general cultural exception in the WTO agreements. ${ }^{40}$ However, it might also be regarded as accommodating aspects of the ideology underpinning the WTO through its uncritical acceptance of the role of private property rights, in the form of intellectual property rights, in sustaining the type of cultural creativity that it regards as essential to the flourishing of cultural diversity. ${ }^{41} \mathrm{~A}$ similar uncritical acceptance characterises the Convention for the Safeguarding of Intangible Cultural Heritage. ${ }^{42}$ Given the historical intertwining of the trade regime and the UNESCO regime, it is probably not surprising that UNESCO's increasing concern with the protection of intangibles has been matched by an enormous growth in the scope and application of intellectual property rights - classically private proprietary rights over intangibles - which are now part of the WTO package in the form of its Agreement on Trade Related Aspects of Intellectual Property (TRIPs Agreement). The minor inconvenience flowing from the fact that this Agreement does not fit within the neoclassical account of free trade upon which the W'TO claims to find its theoretical basis and justification has been conveniently forgotten.

\section{Cultural heritage and decolonisation}

In light of the foregoing, this current period of decolonisation can be regarded as generating three outstanding issues in relation to the question of who owns cultural heritage. These are: first, the question of how we mediate claims that cultural 'stuff' is the common heritage of humanity with the particular claims of developing countries and indigenous peoples; secondly, the question of tangibility and intangibility and its relationship to the privatisation of cultural heritage; and, thirdly, the question of whether it

37 Which recognises in its recitals 'that communities, in particular indigenous communities, groups and, in some cases, individuals, play an important role in the production, safeguarding, maintenance and recreation of the intangible cultural heritage . . ' '; and also recognises the role of communities and groups in Art 2.1.

38 Which makes repeated references to 'traditional cultural expressions' and notes in its Recitals 'the importance of the vitality of cultures, including for persons belonging to minorities and indigenous peoples, as manifested in their freedom to create, disseminate and distribute their traditional cultural expressions and to have access thereto, so as to benefit them for their own development'.

39 UNESCO Convention on the Means of Prohibiting and Preventing the Illicit, Import, Export and Transfer of Ownership of Cultural Property 1970, Art 7(b)(ii).

40 See further C B Graber, 'The New UNESCO Convention on Cultural Diversity: A Counterbalance to the WTO?' (2006) 9 Journal of International Economic Law 553-74.

41 According to its Recitals, the Convention recognises 'the importance of intellectual property rights in sustaining those involved in cultural creativity'; and see Art 20. For a further analysis, see F Macmillan, 'The UNESCO Convention as a New Incentive to Protect Cultural Diversity' in H Schneider and P van den Bossche (eds), Protection of Cultural Diversity from a European and International Perspective (Intersentia 2008) 163-92.

42 See Art 3(b). 
is possible to find a meaningful accommodation of co-existing claims to private and some form of public or communal ownership of cultural heritage.

\subsection{Claims OF DEVELOPING COUNTRIES AND INDIGENOUS PEOPLES}

There are some common issues that arise when considering the question of the mediation of general claims to the common heritage of humanity with particular claims of developing countries and indigenous peoples. Nevertheless, such claims by developing countries and indigenous peoples are distinct and should not, therefore be elided. For developing countries, attempting to build a national identity, sometimes from scratch, and to forge it around often invented/artificially constructed national symbolism, the failure to return significant forms of cultural heritage has been in some cases viewed as a denial of the right to exist. ${ }^{43}$ Despite the statist focus of the UNESCO Conventions, they have been of little assistance to developing countries with respect to tangible cultural heritage because of their resolutely non-retroactive effect. The irony of this is particularly marked in relation to the Convention on the Means of Prohibiting and Preventing the Illicit Import, Export and Transfer of Ownership of Cultural Property, Article 2 of which provides:

The States Parties to this Convention recognize that the illicit import, export and transfer of cultural property is one of the main causes of the impoverishment of the cultural heritage of the countries of origin of such property and that international co-operation constitutes one of the most efficient means of protecting each country's cultural property against all the dangers resulting there from.

The fact that the Convention and its more recent partner the UNIDROIT Convention on Stolen or Illegally Exported Cultural Objects of $1995^{44}$ apply to moveable tangible property and that both Conventions clearly envisage that such property is national in nature would seem to make them well adapted to the task of recognising the cultural interests at play here. However, the Conventions only apply to activities undertaken from the time they came into force, ${ }^{45}$ which means they are more or less irrelevant, in a strictly legal sense, to the claims of developing countries for restitution of objects removed during the colonial period. On the other hand, symbolically they might be regarded as stating an ethical position that should be recognised by the international community. ${ }^{46}$ In this respect, it is interesting to note that the UNIDROIT Convention notes that, despite its lack of retrospectivity, it:

does not in any way legitimise any illegal transaction ... which has taken place before the entry into force of this Convention ... nor limit any right of a State or other person to make a claim under remedies available outside the framework of this Convention for the restitution or return of a cultural object stolen or illegally exported before the entry into force of this Convention.

43 For a discussion of the importance of the restitution of cultural artefacts to former colonial states, see Vrdoljak (n 26) 200-06.

44 Which introduces a more complex legal architecture in order to support the UNESCO Convention on the Means of Prohibiting and Preventing the Illicit Import, Export and Transfer of Ownership of Cultural Property.

45 UNESCO Convention on the Means of Prohibiting and Preventing the Illicit Import, Export and Transfer of Ownership of Cultural Property, Art 7; UNIDROIT Convention on Stolen or Illegally Exported Cultural Objects of 1995, Art 10.

46 Although the Convention on the Means of Prohibiting and Preventing the Illicit Import, Export and Transfer of Ownership of Cultural Property, Art 4, makes cultural property that has been removed with the consent of the competent authorities (paras (c) and (e)) or 'been the subject of a freely agreed exchange' part of the patrimony of the state in which it is located. The application of this provision to artefacts taken during the colonial period would be the source of endless conflicts about what was 'looted' and what was not. As argued above, in the postcolonial context this is not only difficult to substantiate, but more importantly beside the point. 
For indigenous groups, the question of the right to control of cultural heritage is linked to questions of identity, survival and the political project of self-determination, in a world that is dominated by the Westphalian state-based system of sovereignty and law-making. Representing some changes in political awareness, the 1995 UNIDROIT Convention recognises the existence of 'national, tribal, indigenous or other communities' and introduces some procedural rules about claims in the light of this. Its applicability is, of course, limited by the problem of retrospectivity. However, given that indigenous peoples lack the protection of statehood and are still at the whim of the nation states in which they live, the Convention might be regarded as having slightly more utility in a temporal sense. Running counter to this suggestion are the facts that: first, the Convention envisages the need for a co-operative relationship between these groups and the state or states in which they live in relation to the international claims for return with which it is concerned; and, secondly, the fact that it only deals with international claims means that it says nothing about claims by indigenous peoples against the states in which they live. It is interesting, perhaps to note that, in any case, of the most important states for these purposes, ${ }^{47}$ only New Zealand is a member of the UNIDROIT Convention.

\subsection{TANGIBILITY, INTANGIBILITY AND THE PRIVATISATION OF CULTURAL HERITAGE}

In cultural terms, the significance of the distinction between tangible and intangible heritage can be easily exaggerated. This is because what makes a tangible item heritage is precisely its symbolic value. In other words even tangible items are only heritage because of an intangible connection. ${ }^{48}$ This putative distinction, which is derived from occidental legal ordering, is, however, reflected in the UNESCO approach to the protection of cultural heritage. While UNESCO's twentieth-century Conventions focused largely on the question of the protection of tangibles, this century has seen a turn towards the protection of the intangible with the conclusion of the eponymous Convention for the Safeguarding of Intangible Cultural Heritage and of the Convention on the Protection and the Promotion of the Diversity of Cultural Expressions. In fact, both Conventions disrupt to some extent the previous practice of attempting to separate the tangible and the intangible. The Convention on Intangible Cultural Heritage includes within its definition of intangible cultural heritage 'instruments, objects, artefacts and cultural spaces' associated with 'practices, representations, expressions, knowledge, skills . . that communities, groups and, in some cases, individuals recognize as part of their cultural heritage'. ${ }^{49}$ The Cultural Diversity Convention recognises that both the tangible and intangible are part of the diversity of cultures. ${ }^{50}$ Neither Convention, however, has much to offer to either indigenous peoples or developing countries when it comes to the protection of their intangible cultural heritage, despite their objections to the Western appropriation of a wide range of things such as traditional medical or environmental knowledge, know-how, stories, artistic styles, music, dance, festivals, carnivals and other ceremonies. This appropriation, apart from being problematic in itself, has raised problems with respect to inappropriate use. ${ }^{51}$ There are also circumstances in which this appropriation can interfere with the ability of indigenous peoples or communities in the developing world to access, use and reflect

47 Meaning states within which there are substantial groups of indigenous peoples, such as Australia, Canada, New Zealand and the United States.

48 See Blake (n 1) 67-69.

49 UNESCO Convention for the Safeguarding of the Intangible Cultural Heritage, Art 2.1.

50 E.g. through its recognition of the role of 'cultural goods': UNESCO Convention on the Protection and Promotion of the Diversity of Cultural Expressions, Art 4.4.

51 For a full discussion of this problem, see Yu (n 18). 
upon their own intangible cultural heritage. This happens as a consequence of appropriation of this heritage by making it subject to intellectual property rights, which is considered below.

However, it should be noted that the problems of access to intangible heritage are not limited to the issue of private appropriation through intellectual property rights. As Stoler has shown, developing countries have also suffered from another problem with respect to access to their intangible cultural heritage. ${ }^{52}$ This relates to access to information on state administration during the colonial period. While the 1983 Vienna Convention on the Succession of States in Respect of State Property, Archives and Debts required the return of some types of state papers and archives, it does not address the 'know-how' of state administration (including the legal system) with the result that many developing counties claim that effective state-building has been almost impossible. ${ }^{53}$

\subsection{Public Versus private Claims to cultural heritage}

The problem of mediating co-existing claims to private and some form of public or communal ownership of cultural property is a problem that exists with respect to both tangibles and intangibles. As already noted, the importance of respecting private property rights in relation to moveable heritage was regarded as so paramount by the metropolitan powers that the UNESCO Convention on the Means of Prohibiting and Preventing the Illicit Import, Export and Transfer of Ownership of Cultural Property makes special provision to ensure that it is respected and that proper compensation is paid to a property holder. If anything, the situation with respect to the protection of private property rights over intangible forms of cultural heritage is even more biased in favour of the private right holder, with this century's UNESCO Conventions simply ceding the ground. ${ }^{54}$ Certainly, this accommodating approach does nothing to contradict claims that appropriation through intellectual property is the new form of imperialism. ${ }^{55}$ For developing countries and indigenous peoples, not only is there the problem of the appropriation of cultural heritage through a discourse that claims their heritage as the patrimony of humankind - some sort of global patrimony - but also, the problem of the appropriation by private corporate interests, usually in the global north, of intangible heritage. The types of intangible cultural heritage that might be appropriated through intellectual property rights have already been mentioned. So far as, for example, traditional medical knowledge is concerned, there is a plethora of examples of the way in which this type of intangible heritage can be appropriated by pharmaceutical corporations through the use of patents. Similarly, for example, with respect to stories, songs and music there are serious issues about the appropriation of intangible heritage by, for example, the entertainment industry represented by the Hollywood machine. (Of course, the recent development of national film industries in countries like Nigeria and South Korea, as well as the continuing power of Bollywood, constitutes a welcome counter-movement to the Hollywood machine.)

Not only does all this add another possible layer onto the question of 'Who owns cultural heritage?', but it also means that somehow the relationship between the private rights and the more public or communal rights inherent in identifying something as cultural heritage must be negotiated. A negotiation of this type must depend upon some choice as

52 L A Stoler, 'Colonial Archives and the Arts of Governance' (2002) 2 Archival Science 87-109.

53 See Vrdoljak (n 26) 205.

54 See text accompanying nn 41 and 42.

55 See e.g. Rendix (n 9) 191-92. See also Slaughter (n 1) especially 198-99, who argues that the distinction between the developed and developing world is reflected in the idea that the former has intellectual property whilst the latter has cultural property, which is always under threat of appropriation. 
to which rights should prevail. In the postcolonial context, there is a strong argument in favour of giving precedence to cultural heritage rights over intellectual property rights and other private property rights. Three arguments might be cited in support of this proposition. The first is simply that the importance of cultural heritage to processes like nation-building and self-determination, as well as its importance for the identity of indigenous peoples, should be regarded as giving it precedence over private rights on the grounds of ethics, justice and the right to development. Secondly, it could be argued that, in relation to tangible heritage, the international community has already made a political choice to favour cultural heritage rights over private property rights. This choice is expressed in both the UNESCO Convention on the Means of Prohibiting and Preventing the Illicit Import, Export and Transfer of Ownership of Cultural Property and the UNIDROIT Convention on Stolen or Illegally Exported Cultural Objects of 1995, in which private property rights are recognised by a right to compensation in certain circumstances, but cannot be relied upon to prevent the return of stolen or illegally exported cultural artefacts. This approach dovetails with the third argument in favour of preferring cultural heritage claims over private property claims, which is that this approach gives scope to both types of claims whereas giving precedence to private property claims effectively extinguishes cultural heritage claims. Whether property said to constitute cultural heritage is tangible or intangible, its essential features seem to be: first, that it is 'owned' publicly or, at least, in common; and, secondly, that the ownership rights focus on preservation (loosely conceived), access and the sharing of benefits associated with it. These rights cannot be exercised if private property rights are given precedence. Certainly, it is also true that one of the most significant roles of cultural heritage rights is to prevent or limit the privatisation of that cultural heritage. Sometimes this might mean preventing the possibility of private ownership rights altogether, but this is not necessarily the case. There may be circumstances, particularly with respect to intellectual property rights, where the range of rights holders might be circumscribed without preventing more general access. ${ }^{56}$ In any case, it should be possible to find mechanisms either in property law, including intellectual property law, or external to it that carve a public or communal space out of the privatised space of property law. ${ }^{57}$ The fact that the law, to date, has a poor track record in this respect only invests the project with more urgency.

\section{Conclusion?}

What does it mean, in the end, to say, as UNESCO instruments do with such predictable regularity, that cultural heritage is the common heritage of humanity? Is it a claim to ownership or is it a justification for special status and protection? Is it a ground upon which to argue, for example, that diversity is what makes us human? Or a ground upon which to argue that wanton acts of destruction harm the humanity of us all? As Blake notes, there is an 'inherent contradiction' in characterising something as the common heritage of humanity 'while at the same time noting its power in asserting the cultural identity of the community which produced it'. ${ }^{58}$ Yet the assertion of a general claim on the basis of common humanity is not without value.

History shows us that it is not possible to decouple cultural heritage from particular identities, national, communal or otherwise. But it is not clear that this always implies the

56 This is the gist of the UN Declaration on the Rights of Indigenous Peoples, Art 31.1, quoted in full in section 2 above.

57 For an argument to this effect with respect to intellectual property rights, see F Macmillan, 'Many Analogies, Some Metaphors, Little Imagination: The Public Domain in Intellectual Space' (2010) 2 Pòlemos 25-44.

58 Blake (n 1) 64. 
right to make a claim for 'ownership', which might in any case be better understood as a form of stewardship. ${ }^{59}$ Political context is clearly significant here. The postcolonial context, with its urgent demands for justice, makes claims for return of artefacts by indigenous peoples in Australia, for example, different to claims by right-wing governments or political parties in Europe. The pressing need to recognise that cultural heritage is critical to identity, nation-building and sovereignty, and that any notion of a right to development is meaningless without these things, does not just mean that the claims by developing countries to the return of their artefacts taken during the colonial period must be taken seriously by the international community. It also requires a recognition that they have rights over their intangible heritage which impact on, for example, its wholesale appropriation as part of the Hollywood machine.

'Too much', Lowenthal writes, 'is asked of heritage. In the same breath we commend national patrimony, regional and ethnic legacies and a global heritage shared and sheltered in common. We forget that these aims are usually incompatible. ${ }^{60}$ If the cultural heritage claims arising from the oppressive legacy of the colonial period were accepted on the basis that in the name of a right to development they are politically distinguishable from other types of claims, we might find this problem easier to resolve. Attention could then be turned to asking even more of heritage - or at least of rights in relation to it. Now we need heritage rights to fend off the new imperialism of private appropriation of culture, especially as it operates through the global system of intellectual property rights ushered in through the WTO TRIPs Agreement.

59 See K A Carpenter, S Katyal and A Riley, 'In Defense of Property' (2009) Yale Journal of Law 100-204.

60 D Lowenthal, The Heritage Crusade and the Spoils of History (Viking 1997) 227, cited in Blake (n 1) 64. 